\title{
Asymmetric proptosis as a presenting symptom of Hashimoto's thyroiditis with hypothyroidism
}

\author{
Tina George, ${ }^{1}$ Riddhi Dasgupta, ${ }^{2}$ Harsha Vardhan, ${ }^{1}$ Nihal Thomas ${ }^{1}$
}

'Department of Medicine, Christian Medical College and Hospital Vellore, Vellore, India ${ }^{2}$ Department of Endocrinology, Diabetes and Metabolism, Christian Medical College, Vellore, India

\section{Correspondence to} Dr Riddhi Dasgupta, riddhi_dg@rediffmail.com

Accepted 25 February 2018

\section{DESCRIPTION}

Thyroid ophthalmopathy is usually associated with Graves' disease; however, in $6.2 \%$ of patients with thyroid eye disease it can be associated with hypothyroidism. ${ }^{1}$ A 54-year-old woman from Tamil Nadu presented to our outpatient department with sudden onset of binocular diplopia for the past 5 months. She subsequently noticed that her right eye became more prominent than her left eye. She had no other focal deficits or features of raised intracranial pressure. Along with these ocular symptoms, the patient had fatigue and increased drowsiness over the past 5 months and had gained around 3 $\mathrm{kg}$ of weight over the same duration. She however did not complain of constipation, voice changes, pedal swelling, cold intolerance or facial puffiness. She had no features suggestive of hyperthyroidism in the form of tremors, increased sweating, palpitations, hyperdefecation or restlessness. She had no history of hyperthyroidism. She had no history of receiving treatment for hypothyroidism or hyperthyroidism. There were no associated symptoms of neck swelling noticed by the patient; neither did she complain of any compressive symptoms. She also had no history to suggest associated autoimmune disorders.

The patient was evaluated elsewhere initially for these complaints and found to have thyroid-stimulating hormone (TSH) of $0.31 \mu \mathrm{IU} / \mathrm{mL}$ and a free T4 of $1.5 \mathrm{ng} \%$. She also underwent an MRI of the

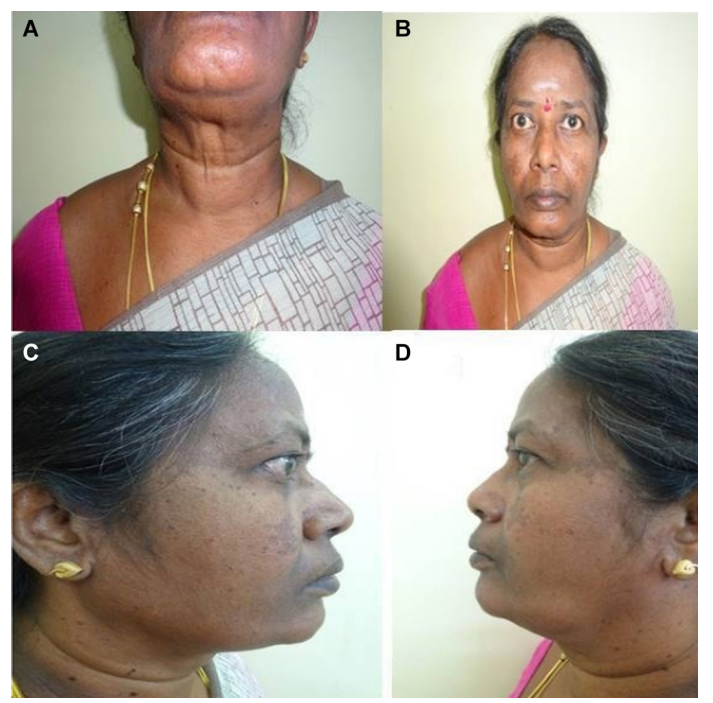

Figure 1 (A) Diffusely enlarged thyroid gland. (B) Exophthalmos of the right eye more than the left eye. (C, D) Proptosis of the right eye compared with the left eye with no proptosis.

brain at that stage which did not show any significant abnormality. She was suspected to have myasthenia gravis and was started on neostigmine for the same with which she had some improvement in her diplopia; however, she stopped her medications 1 month prior to presentation and did not have any worsening of symptoms. She presented to us at this stage with persistent protrusion of the right eye. She had no pain, watering or diminished vision in the right eye. She had no features suggestive of hyperthyroidism, but had noticed that her menstrual cycles were irregular. On examination her pulse rate was $80 / \mathrm{min}$ and blood pressure was $120 / 70 \mathrm{~mm} \mathrm{Hg}$. She had a diffusely enlarged firm thyroid gland (figure 1A). She was found to have asymmetric proptosis of the right eye with lid retraction and lid lag (figure $1 \mathrm{~B}, \mathrm{C}$ ) without evidence of proptosis in the left eye (figure 1D).

Her ophthalmometry (Hertel's) reading at $95 \mathrm{~mm}$ was $21 \mathrm{~mm}$ in the right eye and $20 \mathrm{~mm}$ in the left eye. Ocular movements were restricted in abduction. Pressure in straight gaze was $80 \mathrm{~mm} \mathrm{Hg}$ in the right eye and $14 \mathrm{~mm} \mathrm{Hg}$ in the left eye. Pressure

A

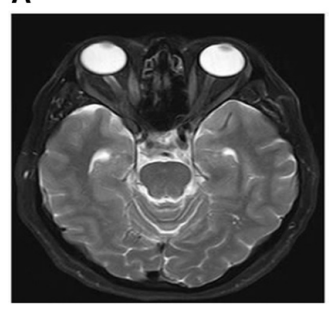

B

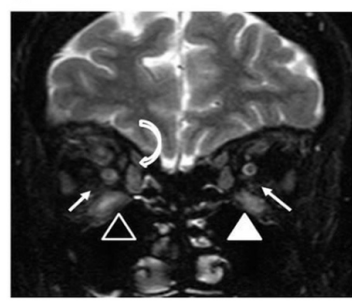

C

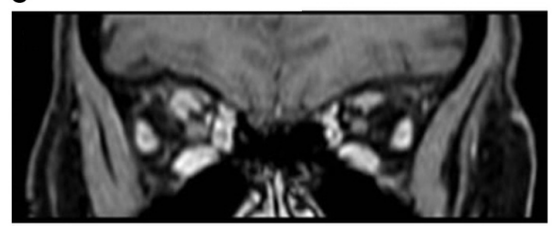

Figure 2 (A) Fat-saturated T2-weighted axial image at level of the orbits showing mild right proptosis. Note the increased bulk of the right medial rectus compared with the left with sparing of the tendinous insertion.

(B) Fat-saturated T2-weighted coronal image of the orbit shows increased bulk of the right inferior rectus (open arrowhead), right medial rectus (curved arrow) and the left inferior rectus (solid arrowhead) with T2 hyperintense signal within the muscles suggestive of oedema. In addition, there is 'dirty' appearance of the retro-orbital fat in both orbits due to inflammation (white arrows).

(C) Postcontrast fat-supressed T1-weighted coronal image of the orbits shows increased enhancement of the involved muscles. 
in upgaze was $22 \mathrm{~mm} \mathrm{Hg}$ in the right eye and $16 \mathrm{~mm} \mathrm{Hg}$ in the left eye. However, her visual fields and fundus were normal. Other system's examination was normal. In view of asymmetric proptosis of the eyes and lack of features of thyrotoxicosis, the possibilities of asymmetric thyroid eye disease, retro-orbital/ orbital mass, or granulomatous diseases were considered. In view of the partial improvement of symptoms with neostigmine, the possibility of myasthenia though unlikely was also considered and she was evaluated for these.

Her investigations revealed a TSH of $42.797 \mu \mathrm{IU} / \mathrm{mL}$, total T4 of $7.3 \mathrm{mcg} \%$, free T4 of $0.8 \mathrm{ng} \%$ with anti-thyroperoxidase antibodies $(1683 \mathrm{IU} / \mathrm{mL})$ and anti-thyroglobulin antibodies $(697$ $\mathrm{IU} / \mathrm{mL}$ ) with normal TSH receptor antibodies $(0.36 \mathrm{IU} / \mathrm{L})$. The workup for myasthenia including anti-acetylcholine receptor antibodies and repetitive nerve stimulation testing were negative.

The MRI of the orbit showed the findings as in figure $2 \mathrm{~A}-\mathrm{C}$. Thus, a diagnosis of autoimmune thyroiditis (Hashimoto's) with hypothyroidism and asymmetric thyroid ophthalmopathy was made. Our patient was started on levothyroxine $(100 \mathrm{mcg} /$ day $)$ with which she improved and her proptosis also abated gradually over the next 3-4 months. Due to the significant clinical improvement in her proptosis at first follow-up at 4 months and owing to her poor financial condition, a repeat MRI of the orbits was deferred until 6 months post-therapy. She was lost to follow-up after the initial visit. Unilateral proptosis can be an ominous sign. However, rarely it can be due to thyroid-associated eye disease which itself may be associated with hypothyroidism rather than hyperthyroidism. ${ }^{2}$

Contributors TG and RD have contributed to the planning, conception and design, acquisition of data or analysis and interpretation of data, drafting of article and final revision. HV has contributed to the planning, conception and design, interpretation of data and final revision. NT has contributed to the planning, conception and design, data analysis, final revision and approval for submission. Agreement to be accountable for the article and to ensure that all questions regarding the accuracy or integrity of the article are investigated and resolved lies with the corresponding author.

Funding This research received no specific grant from any funding agency in the public, commercial or not-for-profit sectors.

Competing interests None declared.

\section{Patient consent Obtained.}

Provenance and peer review Not commissioned; externally peer reviewed.

(C) BMJ Publishing Group Ltd (unless otherwise stated in the text of the article) 2018. All rights reserved. No commercial use is permitted unless otherwise expressly granted.

\section{REFERENCES}

1 Kashkouli MB, Kaghazkanani R, Heidari I, et al. Bilateral versus unilateral thyroid eye disease. Indian J Ophthalmol 2011;59:363-6.

2 Eckstein AK, Lösch C, Glowacka D, et al. Euthyroid and primarily hypothyroid patients develop milder and significantly more asymmetrical Graves ophthalmopathy. Br J Ophthalmol 2009:93:1052-6.

Copyright 2018 BMJ Publishing Group. All rights reserved. For permission to reuse any of this content visit

http://group.bmj.com/group/rights-licensing/permissions.

BMJ Case Report Fellows may re-use this article for personal use and teaching without any further permission.

Become a Fellow of BMJ Case Reports today and you can:

- Submit as many cases as you like

- Enjoy fast sympathetic peer review and rapid publication of accepted articles

- Access all the published articles

Re-use any of the published material for personal use and teaching without further permission

For information on Institutional Fellowships contact consortiasales@bmjgroup.com

Visit casereports.bmj.com for more articles like this and to become a Fellow 